\title{
ANALISIS PAJAK, TUNNELING, GROSS MARGIN, DAN KAP SPESIALIS TERHADAP KEPUTUSAN UNTUK MELAKUKAN TRANSFER PRICING
}

\author{
Lalu Takdir Jumaidi \\ Bambang \\ Robith Hudaya \\ Universitas Mataram
}

\begin{abstract}
The purpose of is to find out the causal relationship from Tax Independent variable, Turnneling, Gross Margin and KAP Specialist toward transfer pricing decision. The result of the statistic analysis shows that only Tax Independent variable influences to transfer pricing decision. Whereas the other variables such as Gross Margin and KAP Specialist are not significantly influencing decision, either partially or simultaneously. This happens because in multinasional automotive industry corporation has a profit increase pattern. The formula of increasing profit company mostey uses managemen evaluation appoach and that of increasing management permance uses management strategy approach, such as total quality managenent with ABS, JIT, EOQ, BEP, cost application standard, and Balanceskorecard models, while tax variable influence very much transfer pricing attitude, because the variable deplets very much company profit, on the other hard, the tax price is relatively different from one contry to another and thust, the tax variable influences very much the decesion to perform Trasfer Pricing.

Key Word: Trasfer Pricing, Gross Margin, Tunneling, KAP Spesialis
\end{abstract}

\section{PENDAHULUAN}

Pesatnya pertumbuhan ekonomi dewasa ini membawa fenomena baru dalam Perkembangan ekonomi yang terjadi dewasa ini, yang dapat memberikan suatu pengaruh besar bagi pola bisnis dan sikap bagi para pelaku bisnis dimana perusahaan berlomba-lomba untuk meningkatkan produktivitas usahanya dengan meningkatkan profit yang optimal di sisi lain perusahaan juga dituntut untuk lebih efisien dalam mengeluarkan biaya-biaya operasional. secara tidak langsung dapat mendorong merebaknya konglomerasi dan divisionalisasi/departementasi perusahaan. Era globalisasi telah membawa dampak semakin meningkatnya transaksi transnasional atau cross-border transaction. Arus barang, jasa, modal, dan tenaga kerja juga 
semakin mudah dan lancar antarnegara. Belum lagi dengan kehadiran WTO (World Trade Organization) dan MEA (Masaarakat Ekonomi Asia) yang mulai berlaku awal tahun 2016 ini yang dapat memfasilitasi perdagangan transnasional. Dalam lingkungan perusahaan multinasional dan konglomerasi serta divisionalisasi terjadi berbagai transaksi antar anggota (divisi) yang meliputi penjualan barang dan jasa, lisensi hak dan harta tak berwujud lainnya, penyediaan pinjaman dan lain sebagainya (Mangoting, 2000). Dengan adanya usaha konglomerasi ini, kita mengenal berbagai nama grup perusahaan terkenal yang merambah dunia bisnis secara nasional, regional maupun internasional (multinational corporations). Selanjutnya perusahaanperusahaan ini membentuk holding company untuk mengkoordinasikan bisnis mereka. Dalam perusahaan tersebut, biasanya sebagian besar aktivitas bisnis terjadi diantara mereka sendiri. Dalam menentukan harga, imbalan, dan lain sebagainya antar mereka biasanya ditentukan berdasarkan kebijakan harga transfer (transfer pricing) yang ditentukan oleh holding company dengan harga yang tidak sama dengan harga pasar (Gusnardi, 2009).

Skema yang biasa digunakan oleh perusahaan multinasional dalam praktik transfer pricing adalah dengan cara mengalihkan keuntungan mereka dari negara yang tarif pajaknya tinggi ke negara lain yang tarif pajaknya lebih rendah. Negara Indonesia termasuk negara yang mempunyai tarif item pajak yang lebih tinggi dibanding dengan negara negara Asia sehingga beberapa perusahaan memungkinkan untuk melakukan transfer pracing antar negara tetangga yang memiliki tarif pajak yang lebih kompetitif. Banyak perusahaan multinasional selama ini tidak menjalankan kewajiban perpajakannnya secara benar yang diakibatkan oleh adanya transfer pricing kepada negara (www.pajak.go.id). Gunadi mengatakan bahwa, "Transfer pricing adalah penentuan harga atau imbalan sehubungan dengan penyerahan barang,jasa atau pengalihan teknologi antar perusahaan yang mempunyai hubungan istimewa" (Suandy, 2011: 71).

Harga wajar atau laba wajar adalah harga atau laba yang dilakukan antara pihak-pihak yang tidak mempunyai hubungan istimewa dalam kondisi sebanding, atau harga atau laba yang ditentukan oleh kekuatan pasar, sehingga transaksi tersebut mencerminkan harga pasar yang wajar atau harga atau laba yang memenuhi prinsip kewajaran dan kelaziman usaha.

Transfer pricing yang dilakukan oleh perusahaan multinasional didorong oleh alasan pajak maupun bukan pajak. Seiring dengan perkembangan zaman, praktik transfer pricing sering kali dilakukan untuk meminimalkan 
jumlah pajak yang harus dibayar (Mangoting, 2000: 80). Beban pajak yang semakin besar memicu perusahaan untuk melakukan transfer pricing dengan harapan dapat menekan beban tersebut. Transfer pricing dalam transaksi penjualan barang atau jasa dilakukan dengan cara memperkecil harga jual antara perusahaan dalam satu grup dan mentransfer laba yang diperoleh kepada perusahaan yang berkedudukan di negara yang menerapkan tarifpajak yang rendah. Namun karena belum tersedianya alat, tenaga ahli, dan peraturanyang baku maka pemeriksaan transfer pricing sering kali dimenangkan oleh wajibpajak dalam pengadilan pajak sehingga perusahaan multinasional semakin termotivasi untuk melakukan transfer pricing (Julaikah, 2014).

Selain alasan pajak, praktik transfer pricing pun dapat dipengaruhi oleh alasan non pajak seperti kepemilikan asing dan ukuran perusahaan. Perusahaan di Asia kebanyakan memiliki struktur kepemilikan yang terkonsentrasi (Dynaty dkk, 2011: 2). Dalam struktur kepemilikan yang terkonsentrasi, pemegang saham pengendali memiliki posisi yang lebih baik karena pemegang saham pengendali dapat mengawasi dan memiliki akses informasi yang lebih baik dibanding pemegang saham non pengendali sehingga menimbulkan potensi pada pemegang saham pengendali untuk terlibat jauh dalam pengelolaan perusahaan. Pemegang saham pengendali menurut PSAK No. 15 adalah entitas yang memiliki saham sebesar $20 \%$ atau lebih baik secara langsung maupun tidak langsung sehingga entitas dianggap memiliki pengaruh signifikan dalam mengendalikan perusahaan. Pemegang saham pengendali dapat dimiliki oleh seseorang secara individu, pemerintah, maupun pihak asing.Pada saat kepemilikan saham yang dimiliki pemegang saham pengendali asing semakin besar, pemegang saham pengendali asing memiliki kendali yang semakin besar dalam menentukan keputusan dalam perusahaan yang menguntungkan dirinya termasuk kebijakan penentuan harga maupun jumlah transaksi transfer pricing. (Sari, 2012: 162). Hal ini dimungkinkan bahwa kepemilikan asing dapat mempengaruhi banyak sedikitnya transfer pricing yang terjadi.

Adanya keterikatan hubungan istimewa di Indonesia, diatur dalam Pasal 18 UU No.36/2008 yaitu penyertaan modal minimal 25 persen, keterkaitan pengelolaan manajemen dan hubungan keluarga sederajat sedarah maupun semenda. Apabila wajib pajak tidak bisa menunjukkan bukti 
pendukung kewajaran harga transaksi, maka Ditjen Pajak akan menetapkan harga transaksi yang wajar antara pihak-pihak yang terafiliasi. Namun ada pengecualian, kewajiban pelaporan Trasfer Pricing dibatasi untuk nilai minimal sebesar Rp.10 milyar dalam satu tahun pajak. Menjerat perusahaan yang melakukan transfer pricing bukan urusan gampang. Ketiadaan akses publik ke dalam detil rincian transaksi perusahaan, menyebabkan perusahaan leluasa memodifikasi laporan keuangan. Bahkan perusahaan terbuka (Tbk) mungkin juga melakukan Transfer pricing. Bahkan Transfer pricing tidak hanya dilakukan antara pihak-pihak yang memiliki hubungan istimewa. Transaksi antara perusahaan yang sama sekali tidak hubungan istimewa, juga bisa dilakukan under invoice, untuk mengecilkan omset penjualan.

Aturan PER-32/PJ/2011 menyatakan bahwa penentuan harga transaksi wajar (arm's length price) bisa melalui metode perbandingan harga antara pihak non istimewa, resale price dan metode lainnya.Syarat utama analisis ini adalah ketersediaan data pembanding eksternal maupun internal. Karena keterbatasan akses data yang dimiliki penulis akan mencoba menelusuri kewajaran transaksi dengan membandingkan perkembangan Gross Margin dengan perkembangan omzet penjualan selama kurun waktu penelitian

apakah rasiao kenaikan omzet akan sebanding dengan kenaikan Gross margin.

\section{Rumusan Masalah}

Sehubungan dengan latar belakang tersebut, penelitian ini membahas tentang (1) pengaruh pajak terhadap keputusan dalam melakukan Transfer pricing,(2) pengaruh Tunneling terhadap keputusan dalam melakukan transfer pricing, (3) pengaruh Gross Margin terhadap keputusan dalam melakukan transfer Pricing, dan (4) pengaruh KAP Spesialis keputusan untuk melakukan Tansfer Praicing.

\section{TINJAUAN PUSTAKA}

\section{Penelitian Terdahulu}

Penelitian Ni Wayan Yuniasih, Ni Ketut Rasmini, Made Gede Wirakusuma (2012) yang meneliti mengenai pengaruh pajak dan tunneling incentive pada keputusan transfer pricing Perusahaan Manufaktur yang Listing di Bursa Efek Indonesia. Dalam penelitian ini mengungkapakan adanya pengaruh positif 
dari pajak dan tunneling terhadap keputusan transfer pricing yang dilakukan oleh perusahaan.

Peneliti Winda Hartati dan Desmiyawati yang meneliti mengenai Tax Minimization, Tunneling Incentive, dan mekanisme bonus terhadap transfer pricing pada seluruh perusahaan yang listing di BEI (Bursa Efek Indonesia)

Penelitian lainnya yang berkaitan dengan transfer pricing yaitu penelitian yang dilakukan oleh (Richardson,Grant et al., 2013). Dimana penelitian yang berjudul Determinants of transfer pricing aggressiveness: Empirical evidence from Australian firms. Penelitian ini menyimpulkan bahwa profitabilitas, leverage, aset idak berwujud, dan multinationality berhubungan positif terhadap transfer pricing agresivitas. Sedangkan hasil dari regresi tambahan menunjukkan transfer pricing meningkat melalui aset tidak berwujud dan multinationality, serta adanya variabel kontrol yang digunakan yaitu ukuran perusahaan dan sektor industry.

Penelitian yang dilakukan Kiswanto, Nancy dan Purwangsih, Anna (2014) dengan judul Pengaruh Pajak, Kepemilikan Asing, dan Ukuran Perusahaan terhadap Transfer Pricing pada perusahaan Manufaktur di BEI Tahun 2010-2013. Hasil penelitian menunjukkan bahwa variabel pajak berpengaruh positif terhadap transfer pricing, kepemilikan asing berpengaruh positif terhadap transfer pricing, dan ukuran perusahaan berpengaruh negatif terhadap transfer pricing.

Hasil penelitian yang dilakukan (Setiawan,2014) yang berjudul Transfer Pricing dan Risikonya Terhadap Penerimaan negara yaitu ada beberapa yang dapat dilakukan oleh pemerintah dalam hal ini Kementerian Keuangan dan Direktorat Jenderal Pajak untuk memitigasi dan meminimalkan risiko kehilangan penerimaan negara akibat dari praktik abuse of transfer pricing : (1) Memperkuat sumber daya manusia yang ahli dalam bidang transfer pricing, (2)Memperkuat institusi yang khusus mengurusi tentang transfer pricing, (3)Meningkatkan kualitas dan kuantitas database serta accessibility terhadap database Tersebut, (4) Menerapkan Advance Pricing Agreement (APA) dengan Wajib Pajak maupun dengan negara lain, dan (5) Menerapkan Mutual Agreement Procedure (MAP) dengan negara lain dengan lebih intensif

\section{Landasan Teoritis dan Hipotesis Penelitian Theori Keagenan ( Agency Theory)}

Konsep teori keagenan adalah hubungan antara prinsipal dan agen (Widyaningdyah 2001). Prinsipal mempekerjakan agen untuk melakukan tugas untuk kepentingan prinsipal, termasuk pendelegasian otoritas pengambilan keputusan dari prinsipal kepada agen. Pada perusahaan yang modalnya terdiri atas saham, pemegang saham bertindak sebagai principal 
sedangkan CEO bertindak sebagai agen mereka. Pemegang saham mempekerjakan CEO untuk bertindak sesuai dengan kepentingan mereka. Teori keagenan memiliki asumsi bahwa masing-masing individu termotivasi oleh kepentingan dirinya sendiri sehingga menimbulkan konflik kepentingan antara prinsipal dan agen. Pihak prinsipal termotivasi mengadakan kontrak untuk mensejahterakan dirinya dengan profitabilitas yang selalu meningkat. Agen termotivasi untuk memaksimalkan kebutuhan ekonomi dan psikologisnya, antara lain dalam hal memperoleh investasi, pinjaman maupun kontrak kompensasi. Konflik kepentingan semakin meningkat karena prinsipal tidak dapat memonitor aktivitas CEO sehari-hari untuk memastikan bahwa CEO bekerja sesuai dengan keinginan pemegang saham.

\section{Transfer Pricing}

Transfer pricing merupakan harga transfer atas harga jual barang, jasa, dan harta tidak berwujud kepada anak perusahaan atau kepada pihak yang berelasi atau mempunyai hubungan istimewa yang berlokasi di berbagai negara (Astuti, 2008: 12). Menurut Plasschaet, definisi transfer pricing adalah suatu rekayasa manipulasi harga secara sistematis dengan maksud mengurangi laba, membuat seolah-olah perusahaan rugi, menghindari pajak atau bea di suatu negara. Rekayasa tersebut bisa memanfaatkan tarif pajak di suatu negara dengan menggeser laba tersebut ke tarif pajak yang paling rendah (Gunadi, 1994: 9 dalam Yuniasih dkk, 2011). Transfer pricing biasanya ditetapkan untuk produk-produk antara (intermediate product) yang merupakan barang-barang dan jasa-jasa yang dipasok oleh divisi penjual kepada divisi pembeli. Pasal 1 ayat (8) Peraturan Direktur Jenderal Pajak Nomor PER-43/PJ./2010 yang diubah terakhir dengan PER-32/PJ./2011, mendefinisikan penentuan harga transfer (transfer pricing) sebagai "penentuan harga dalam transaksi antara pihak-pihak yang mempunyai hubungan istimewa" (Desriana, 2012). Berdasarkan UU Nomor 36 Tahun 2008, hubungan istimewa dianggap ada apabila (Barata, 2011: 147-148):

1) Wajib pajak memepunyai penyertaan modal langsung atau tidak langsung paling rendah $25 \%$ pada wajib pajak lainnya; hubungan antara wajib pajak dengan penyertaan paling rendah $25 \%$ pada dua wajib pajak atau lebih; atau hubungan di antara dua wajib pajak atau lebih yang disebut terakhir.

2) Wajib pajak yang menguasai wajib pajak lainnya atau dua atau lebih wajib pajak berada di bawah penguasaan yang sama baik langsung maupun tidak langsung.

3) Terdapat hubungan keluarga baik sedarah maupun semenda dalam garis keturunan lurus dan/atau ke samping satu derajad. 


\section{Pajak}

Menurut Prof. Dr. P.J.Adriani: "Pajak adalah iuran masyarakat kepada negara (yang dapat dipaksakan) dengan tiada mendapat jasa timbal (kontraprestasi) yang langsung dapat ditunjukkan dan yang digunakan untuk membayar pengeluaran umum" (Waluyo, 2009). Pada pasal 1 UU Pajak Penghasilan, Pajak Penghasilan adalah pajak yang dikenakan terhadap subjek pajak atas penghasilan yang diterima atau diperolehnya dalam tahun pajak. Pajak Penghasilan Badan (PPh Badan) adalah pajak yang dikenakan atas penghasilan yang diterima atau diperoleh oleh Badan seperti yang dimaksud dalam UU KUP (Jewel, 2012). Adapun subjek dari PPh Badan yaitu wajib pajak badan dalam negeri dan wajib pajak badan luar negeri. Yang menjadi objek pajak PPh Badan adalah penghasilan (Jewel, 2012).

\section{KAP Spesialisasi Keahlian Pajak sebagai Variabel Moderating}

Spesialisasi keahlian pajak ini dibidang permasalahan pajak khususnya sangat meningkatkan kinerja professional KAP. Terwujudnya keahlian spesialis yang biasanya terbentuk pada KAP yang besar, dari banyaknya pengalaman demi pengalaman, memberikan banyak kemajuan pengetahuan dalam melaksakan tugas audit pajak secara professional. Variabel ini terbukti dapat mempengaruhi menejerial untuk cendrung melakukan manajemen laba artinya termasuk transfer praicing. Pernyataan ini dipertegas oleh temuan hasil penelitian (Setiawati 2012)

\section{Tunneling}

Tunneling merupakan perilaku manajemen atau pemegang saham mayoritas yang mentransfer aset dan profit perusahaan untuk kepentingan mereka sendiri, namun biaya dibebankan kepada pemegang saham minoritas (Zhang, 2004 dalam Mutamimah, 2008). Sansing (1999) menunjukkan bahwa pemegang saham mayoritas dapat mentransfer kekayaan untuk dirinya sendiri dengan mengorbankan hak para pemilik minoritas, dan terjadi penurunan pengalihan kekayaan ketika persentase kepemilikan pemegang saham mayoritas menurun. Mutamimah (2008) menemukan bahwa terjadi tunneling oleh pemilik mayoritas terhadap pemilik minoritas melalui strategi merger dan akuisisi. Lo et al., (2010) menemukan bahwa konsentrasi kepemilikan oleh pemerintah berpengaruh pada keputusan transfer pricing. Aharony et al., (2010) menemukan bahwa tunneling incentive setelah initial public offering (IPO) berhubungan dengan penjualan hubungan istimewa sebelum IPO

Jadi dapat disimpulkan bahwa yang dimaksud dengan tunneling incentive adalah suatu prilaku dari pemegang saham mayoritas yang 
mentransfer aset dan laba perusahaan demi keuntungan mereka sendiri, namun pemegang saham minoritas ikut menanggung biaya yang mereka bebankan. Dengan adanya pemindahan asset dari suatu perusahaan ke perusahaan lain baik yang mempunyai hubungan istimewa maupun tidak apalagi dilakukan antara negara yang mempunyai tarif pajak yang berbeda dapat menimbulkan transfer pricing yang mengakibatkan kerugian pada negara yang mempunyai tarif pajak yang lebih tinggi.

\section{Gross Margin}

Gross Margin, merupakan perbandingan laba usha yang terjadi setelah dilakukkan harga penjualan dikurangi harga pokok pembelian, perkembangan gross margin dari tahun ke tahun sangat menntukan dalam perkembangan arah dan kebijakan perusahaan, dalam Gross margin para analis bisa melihat perkembangan nilai harga wajar dari tiap tiap perusahaan dengan cara membandingkan dengan perusahaan yang sejenis maupun melalui analisa internal dengan membandingkan perkembangan gross margin satu periode laporan keuangan dengan periode laporan keuangan berturut turut selama beberapa tahun.

\section{Hipotesis Penelitian}

\section{Pajak berpengaruh Positif terhadap Transfer Pricing}

Menurut Prof. Dr. P.J.Adriani: "Pajak adalah iuran masyarakat kepada negara (yang dapat dipaksakan) dengan tiada mendapat jasa timbal (kontraprestasi) yang langsung dapat ditunjukkan dan yang digunakan untuk membayar pengeluaran umum" (Waluyo, 2009). Pada pasal 1 UU Pajak Penghasilan, Pajak Penghasilan adalah pajak yang dikenakan terhadap subjek pajak atas penghasilan yang diterima atau diperolehnya dalam tahun pajak. Pajak Penghasilan Badan (PPh Badan) adalah pajak yang dikenakan atas penghasilan yang diterima atau diperoleh oleh Badan seperti yang dimaksud dalam UU KUP (Jewel, 2012). Adapun subjek dari PPh Badan yaitu wajib pajak badan dalam negeri dan wajib pajak badan luar negeri. Yang menjadi objek pajak PPh Badan adalah penghasilan (Jewel, 2012).

Penelitian yang dilakukan Ni Wayan Yuniasih, Ni Ketut Rasmini, Made Gede Wirakusuma (2012, Pajak, dan tunneling berpengaruh positif terhadap keputusan transfer pricing yang dilakukan oleh perusahaan, begitu juga dengan Nancy Kiswanto dan Anna Purwaningsih (2014), Hasil penelitian menunjukkan bahwa variabel pajak dan kepemilikan asing berpengaruh positif terhadap transfer Pricing,

Dalam hal transfer pricing, perusahaan yang memiliki keuntungan lebih dapat menyesuaikan harga pengalihan untuk mengurangi (peningkatan) 
keuntungan dalam pajak tinggi (pajak rendah). Misalnya, perusahaan seperti Apple, Google dan Microsoft telah mampu menemukan keuntungan dari pajak rendah dan peningkatan pajak pengeluaran (misalnya pembayaran royalti) serta bagaimana perusahaan dengan pajak tinggi untuk mengurangi laba kena pajak, kasusu seperti ini juga terjadi di Indonesia bagaimana Toyota Astra Motor memanfaatkan tarif rendah di Singapura sebagai basis penjualan produksi otomotif yang di produksi dari Indonesia yang memiliki tarif pajak lebih tinggi dari pada di Singapura, maka hipotesis penelitian sebagi berikut :

\section{H1: Pajak berpengaruh Positif terhadap transfer pricing}

\section{Tunneling berpengaruh Positif terhadap transfer pricing}

Suatu perilaku pemegang saham mayoriras atau kepemilikan saham dominan Perpindahan Aktiva dari suatu perusahaan keperusahaan lain baik yang dilakukan antara group perusahaan itu sendiri maupun dengan pihak lain antara satu negara dengan negara yang lain yang memiliki tarif yang berbeda sehingga dapat menimbulkan perpindahan tarif pajak dari satu perusahaan ke perusahaan lain atau baik dalam satu negara maupun antar negara hal ini disebut sebagi Tunnlening Incentive). Secara khusus, penghindaran pajak dapat dicapai melalui transfer pricing dengan mentransfer barang ke negara-negara dengan tingkat pajak penghasilan rendah (misalnya bebas pajak) dan dengan memindahkan barang dari negara-negara tersebut dengan harga pengalihan tertinggi.hal ini sejalan dengan hasil penelitian terdahulu Ni Wyan Yuniasih, Ni Ketut Rasmini, Md Gede Wirakusuma yang menyatakan bahwa Tunnlening berpengaruh positif terhadap Transfer pricing sedangakan hasil penelitian Ratna Candra Sari dan Zaki baridwan (2014 adalah Pada sisi Tunneling Aktiva lancer berpengaruh negative perusahaan yang kepemilikan terkonsentrasi positive terhadap Tunneling disbanding yang kepemilikan menyebar Untuk itu dalam penelitian ini akan menguji dampak pemanfaatan Tunnlening terhadap transfer pricing, maka hipotesis penelitian sebagai berikut:

\section{H2 : Tunnlening berpengaruh Positif terhadap transfer pricing}

\section{Gross Margin Berpengaruh Positif terhadap transfer pricing}

Dalam peraturan Ditjen pajak Nomor PER-32/PJ/2011 menyatakan bahwa, "Harga Wajar atau Laba Wajar adalah harga atau Iaba yang terjadi dalam transaksi yang dilakukan antara pihak-pihak yang tidak mempunyai Hubungan Istimewa dalam kondisi yang sebanding, atau harga atau laba yang ditentukan sebagai harga atau laba yang memenuhi Prinsip Kewajaran dan Kelaziman Usaha 
Gross Margin, merupakan perbandingan laba usaha yang tejdi setelah dilakukkan hrga penjualan dikurangi harga pokok pembelian, perkembangan gross margin dari tahun ke tahun sangat menntukan dalam perkembangan arah dan kebijakan perusahaan, dalam Gross margin para analis bisa melihat perkembangan nilai harga wajar dari tiap tiap perusahaan dengan cara membandingkan dengan perusahaan yang sejenis maupun melalui analisa internal dengan membandingkan perkembangan gross margin satu periode laporan keuangan dengan periode laporan keuangan berturut turut selama beberapa tahun. Hal ini sejalan dengan hasil penelitian Richardson,Grant et al., (2013) dengan hasil penelitian profitabilitas berpengaruh positif terhadap Transfer pricing, sehingga hipotesis penelitiannnya sebagi berikut :

\section{H3: Gross Margin Berpengaruh Positif terhadap transfer pricing}

\section{KAP Spesialisasi Pajak berpengaruh terhadap keputusan untuk melakukan Transfer Pricing}

Perusahaan multinasional menerapkan perencanaan pajak yang efisien di seluruh entitas kelompok, masuk akal bahwa perusahaan dengan anak yang berasal dari sumber pendapatan asing akan memiliki insentif dan kesempatan untuk terlibat dalam penghindaran pajak (Rego, 2003; Hanlon et al., 2007). Misalnya, perusahaan multinasional memiliki kesempatan untuk mengurangi pajak perusahaan dengan menempatkan pemotongan pajak tinggi ke pajak yang rendah dan dengan memanfaatkan berbagai aturan pajak negara yang berbeda (Slemrod, 2001). Bahkan, Slemrod (2001) menyatakan bahwa perusahaan multinasional menggunakan metode perencanaan pajak yang saling terkait secara global dan secara efisien mengurangi kewajiban pajak kelompok multinasional menggunakan metode perencanaan pajak yang saling terkait secara global dan secara efisien mengurangi kewajiban pajak kelompok Rego (2003) menemukan bahwa perusahaan-perusahaan multinasional cenderung lebih berhasil menghindari pajak perusahaan yang mampu mencapai skala ekonomi dalam perencanaan pajak melalui penggunaan operasi yang luas dan perdagangan antarperusahaan. Demikian pula, Dyreng et al. (2008) mengamati bahwa perusahaan dengan eksposur internasional yang lebih besar memiliki lebih banyak kesempatan untuk terlibat dalam strategi penghindaran pajak. Hal ini perlu peran KAP yang memiliki bidang spesialisasi pajak untuk terlibat dalam perencanaan pajak, seperti dalam penelitian yang dilakukan oleh Sean T Mic Gurite, Thomas C omer, Dechun wang (2010) sedangkan pada penelitian Andew M Bauer (2011) menemukan tidak ada hasil yang signifikan antar pengetahuan KAP terhadap pajak yang dapat mempengaruhi Transfer pricing karena Transfer pricing ini adalah murni karena adanya perbedaan tarif antar 
Negara. Untuk memperjelas hasil penelitian ini maka penulis akan mencoba untuk meneliti kembali danpak KAP Spesialis pajak terhadap Transfer pricing Sehingga penelitian ini akan menguji dampak KAP Spesialisasi Pajak pada transfer pricing, sehingga hipotesis penelitiannya sebagai berikut:

\section{H4: KAP Spesialisasi Pajak berpengaruh terhadap keputusan untuk} melakukan Transfer Pricing

\section{Kerangka Konsep Penelitian} berikut :

Berdasarkan penjelasan di atas, disusun kerangka pemikiran sebagai

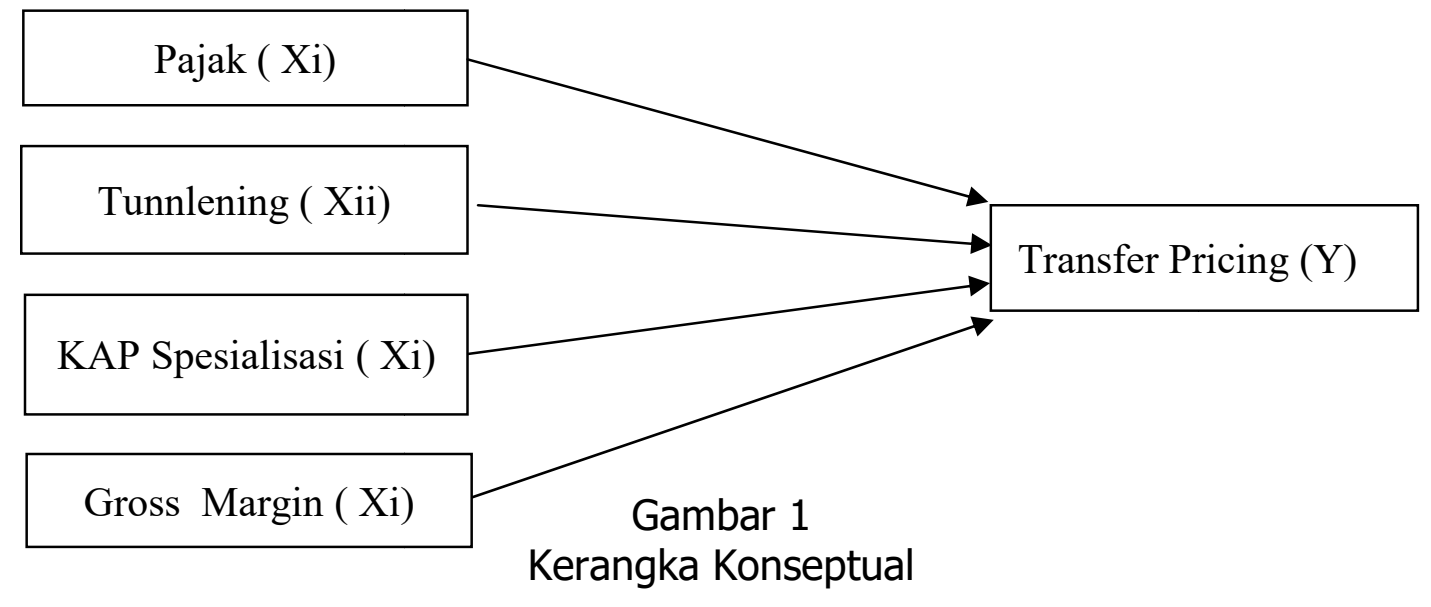

Metode Penelitian

\section{Jenis Penelitian}

Penelitian ini adalah penelitian asosiatif yang bertujuan untuk mengetahui hubungan antara dua variable atau lebih (Siregar, 2014,15), dengan hubungan berjenis sebab akibat (kasual).

\section{Populasi dan Sampel}

Populasi dari penelitian ini menggunakan perusahaan manufaktur yang yang terdaftar pada BEI pada tahun 2011-2015 yang diperoleh dari laporan keuangan tahunan yang diterbitkan oleh BEI melalui situs resmi BEI di www.idx.co.id

Setelah dilakukan eliminisasi atau penyaringan lebih mendalam dengan tehnis purposive sampling, maka sampel perusahaan tersaring menjadi tinggal 6 (enam) sampel. Adapun purposive sampling yang menjadi penyaring adalah (1) Perusahaan outomotif yang tidak melaporkan laporan keuangan berturut-turut periode 2011-2015, (2) Perusahaan automotif yang mengalami pergantian sektor, bisa karena ganti core binis, merger atau 
akuisisi dari tahun 2011-2015, dan (3). Perusahaan automotif yang tidak menggunakan mata uang rupiah. Jadi yang menjadi objek peleitian adalah perusahaan multinasional yang bergerak di bidang industry automotif sejumlah enam (6) perusahaan dan didirikan di Indonesia. Adapun jumlah periode sampel yang diamati adalah lima (5) tahun, jadi jumlah sampel seluruhnya adalah 5 th $\times 6$ entitas $=30$ perusahaan industry automotif.

\section{Jenis dan Sumber Data}

\section{Jenis dan Sumber Data}

Pada penelitian ini data yang digunakan adalah data sekunder. Data sekunder merupakan sumber data penelitian yang diperoleh peneliti secara tidak langsung melalui media perantara yang umumnya berupa bukti, catatan atau laporan yang telah tersusun dalam arsip baik yang dipublikasikan maupun yang tidak dipublikasikan (indriantono, 2002,147). Data sekunder dalam penelitian ini diperoleh dengan melihat laporan keuangan perusahaan yang dipublikasikan oleh BEI melalui situs (www.idx.co .id) Indonesian Capital market Directory (ICMD) dan pusat data bisnis dan ekonomi (PDBE) study pustaka atau literature melalui buku teks, jurnal ilmiah, artikel dan majalah, serta sumber tertulis lainnya yang dibutuhkan, juga dijadikan sumber pengumpulan data

\section{Hasil dan Bahasan \\ Hasil Uji Asumsi Klasik \\ Uji normalitas}

Data yang terdistribusi normal ditunjukkan dengan nilai signifikansi diatas 0,05. menunjukkan bahwa variabel PAJAK, TUNELING, KAP dan GROSS PROFIT MARGIN secara keseluruhan mempunyai nilai signifikansi sebesar 0,653. Nilai ini lebih besar dari 0,05. Dengan demikian dapat disimpulkan bahwa sampel tersebut terdistribusi secara normal dan memenuhi syarat untuk dilakukan penelitian lebih lanjut.

\section{Uji Multikolonieritas}

Berdasarkan tabel di atas, terlihat bahwa hasil uji multikolonieritas dari variabel PAJAK, TUNNELING, GROSS PROFIT MARGIN dan KAP masingmasing memliki nilai tolerance di atas 0,10 dan menunjukkan nilai VIF kurang dari 10 yaitu masing-masing sebesar 1,000. Dengan demikian model regresi tidak terdapat masalah multikolonieritas.Maka model regresi layak digunakan. 


\section{Uji Autokorelasi}

Berdasarkan hasil pengujian autokorelasi dengan uji Durbin-Watson pada tabel, terlihat bahwa nilai DW sebesar 2.226. Jika dibandingkan dengan nilai tabel dengan menggunakan nilai signifikansi 5\%, jumlah sampel 30 (n) dan jumlah variabel independen $4(\mathrm{k}=4)$, maka tabel Durbin-Watson didapatkan nilai du $=1,7386<2.226<2,2614$ jadi dapat disimpulkan tidak terdapat autokorelasi positif ataupun negatif.

\section{Uji Heteroskedastisitas}

Berdasarkan hasil pengujian heteroskedastisitas dengan uji Glejser pada tabel di atas, terlihat bahwa hanya variabel staf ahli pajak atau KAP yang probabilitas signifikansinya masih di bawah 0,05 yaitu sebesar 0.031, sehingga model regresi mungkin mengandung heteroskedastisitas.

\section{Hasil Pengujian Hipotesis}

\section{Model Regresi Linier Berganda}

Penelitian ini menggunakan model regresi berganda, di mana dalam persamaannya mengandung empat variabel independen, keempat variabel independen tersebut adalah KAP, TUNNELING, GROSS PROFIT MARGIN dan PAJAK sebagai. Hasil analisis regresi sederhana dapat dilihat pada tabel 4.6 berikut.

Coefficients $^{a}$

Tabel 1 Hasil Analisis Berganda

\begin{tabular}{|c|c|c|c|c|c|c|}
\hline \multirow{2}{*}{\multicolumn{2}{|c|}{ Model }} & \multicolumn{2}{|c|}{$\begin{array}{l}\text { Unstandardized } \\
\text { Coefficients }\end{array}$} & \multirow{2}{*}{$\begin{array}{l}\text { Standardized } \\
\text { Coefficients } \\
\text { Beta }\end{array}$} & \multirow[t]{2}{*}{$\mathrm{t}$} & \multirow[t]{2}{*}{ Sig. } \\
\hline & & B & Std. Error & & & \\
\hline \multirow{5}{*}{1} & (Constant) & -19.224 & 10.883 & & $\begin{array}{l}- \\
1.766\end{array}$ & .090 \\
\hline & PAJAK & .831 & .348 & .506 & 2.386 & .025 \\
\hline & TUNNELING & .051 & .045 & 258 & 1.144 & .263 \\
\hline & $\begin{array}{l}\text { GROSSPROFIT } \\
\text { MARGIN }\end{array}$ & -.049 & .079 & -.115 & -.617 & .543 \\
\hline & KAP & 1.349 & 1.509 & .181 & .894 & .380 \\
\hline
\end{tabular}

a. Dependent Variable: TRANSFERPRICING

\section{Uji Signifikansi Parameter Individual (Uji Statistik t)}

Pada tabel diatas yang diinterpretasikan adalah nilai dalam kolom B, baris pertama menunjukkan konstanta (a) dan baris selanjutnya menunjukkan konstanta berdasarkan tabel di atas, hanya variabel 
independen PAJAK saja yang signifikan pada 0.05 atau H1 DITERIMA. Dengan demikian, dapat disimpulkan bahwa hanya variabel PAJAK saja yang berpengaruh positif terhadap variabel TRANSFER PRICING pada tingkat signifikansi 0.05. Adapun persamaan yang dapat dibuat sebagai berikut:

$$
Y=-19.224+0,831 X_{1}+0.051 \times 2-0.049 X 3+1.349 X 4+
$$

TRANSFER PRICING $=-19.224+0.831$ Pajak +0.051 Tunneling

$$
-0.049 \text { Gross Profit Margin }+1.349 \text { KAP }+\varepsilon
$$

Dari persamaan diatas dapat diartikan sebagai berikut :

1. Makna konstanta (a) sebesar - 19.224

Hasil ini menunjukkan jika variabel independen bernilai nol, maka nilai variabel dependennya (Transfer Pricing) berkurang sebesar 19.224. Hal ini tidak mungkin terjadi karena nilai pajak, tunneling dan gross profit margin perusahaan tidak mungkin bernilai nol (0),

2. Makna koefisien regresi berganda variabel PAJAK sebesar (0.837)

Variabel PAJAK memiliki nilai koefisien regresi dengan arah positif sebesar 0.837 atau dapat dikatakan pada variabel PAJAK terdapat hubungan positif dengan TRANSFER PREICING. Hal ini menunjukkan bahwa setiap peningkatan pajak sebesar satu akan menyebabkan variabel HARGA TRANSFER juga mengalami peningkatan sebesar nilai koefisien, yaitu 0,837 .

\section{Uji Koefisien Determinasi $\left(\mathbf{R}^{2}\right)$}

Koefisien determinasi $\left(R^{2}\right)$ untuk mengukur seberapa jauh kemampuan model dalam menerangkan variasi variabel dependen.Nilai koefisien determinasi adalah antara nol dan satu.Nilai yang mendekati satu berarti variabel-variabel independen memberikan hampir semua informasi yang dibutuhkan untuk memprediksi variasi variabel dependen (Ghozali, 2005:83).

Tabel 2. Hasil Uji Koefisien Determinasi

\begin{tabular}{|l|l|l|l|l|}
\hline Model & $R$ & R Square & $\begin{array}{l}\text { Adjusted } \\
\text { Square }\end{array}$ & $\begin{array}{l}\text { Std. Error of } \\
\text { the Estimate }\end{array}$ \\
\hline 1 & $.507^{\mathrm{a}}$ & .257 & .138 & 2.97593 \\
\hline
\end{tabular}

a. Predictors: (Constant), KAP, GROSS PROFIT MARGIN, PAJAK, TUNELING

b. Dependent Variable: TRANSFERPRICING 
Dari tabel diatas dapat diketahui bahwa nilai Adjusted $\mathrm{R}$ Square dari PAJAK, TUNNELING, GROSS PROFIT MARGIN dan KAP sebesar 0.138 , yang berarti bahwa $13,8 \%$ variasi transfer pricing dapat dijelaskan oleh keempat variabei independen, yaitu: PAJAK, TUNNELING, GROSS PROFIT MARGIN dan KAP. Sementara itu, sisanya $(100 \%-13.8 \%=86.2 \%)$ disebabkan oleh sebab-sebab atau variabel-variabel yang lain di luar model.

Uji Signikansi Simultan. (Uji Statistik F) Hasil uji statistik F dapat dilihat pada tabel di bawah ini

\begin{tabular}{|ll|ll|l|l|l|l|}
\hline \multicolumn{2}{|l|}{ Model } & & $\begin{array}{l}\text { Sum } \\
\text { Squares }\end{array}$ & of & Mean Square & F & Sig. \\
\hline \multirow{4}{*}{1} & Regression & 76.512 & 4 & 19.128 & 2.160 & $.103^{\mathrm{b}}$ \\
& Residual & 221.404 & 25 & 8.856 & & \\
& Total & 297.916 & 29 & & & \\
\hline
\end{tabular}

a. Dependent Variable: TRANSFERPRICING

b. Predictors: (Constant), KAP, GROSSPROFITMARGIN, PAJAK, TUNELING

Berdasarkan tabel di atas dapat diketahui nilai $\mathrm{F}$ hitung sebesar 2.160 dengan probabilitas 0.103 . Karena probabilitas jauh lebih besar dari 0.05 , maka dapat dikatakan bahwa PAJAK, TUNNELING, GROSS PROFIT MARGIN dan KAP secara bersama-sama/ simultan tidak berpengaruh terhadap TRANSFER PRICING, karena tidak di dukung oleh data.

\section{Interprestasi Hasil (Pembahasan Hipotesis)}

\section{H1 : Pajak berpengaruh Positif terhadap transfer pricing}

\section{H1 DITERIMA}

Hasil analisis statistik menunjukkan variabel pajak berpengaruh signifikan terhadap keputusan melakukan Tranfer Pricing.Kondisi ini dinyyatakan dengan nilai signifikan 0,025 berada dibawah 0.05 . Hasil analisis satistik ini membuktikan dan memperkuat bahwa pajak sangat dominan dari variabel lain berpengaruh signifikan terhadap keputusan Transfer Pricing.

Perusahaan besar melakukan transfer pricing sebagai salah satu alternatif untuk menghindari pajak yang tinggi dengan cara memanipulasi harga secara sistematis dengan maksud mengurangi laba atau membuat seolah-olah perusahaan menjadi rugi. Alternatif yang paling memotifasi entitas melakukan transfer pricing adalah karena adanya pajak.. Pajak ini akan terus semakin kuat mendorong Sobjek Pajak untuk melakukan perilaku transfer pricing jika pajak yang berlaku dianggap tinggi, lebih-lebih dinilai 
sangat tinggi. Ditambah lagi jika diketahui banyak negara-negara yang memilki pengenaan tingkat pajak yang jauh lebih rendah dari negara, tempat aktifitas bisnis berlangsung, maka kondisi ini akan mempengaruhi psikologis entitas untuk melakukan transfer pricing..

Beberapa contoh negara-negara yang memilki tarif pajak rendah dari tariff pajak secara umum, Singapura, Malaysia, Berunai Darussalam. Kondisi perbedaan pajak yang cukup tinggi inilah yang kemudian dominan memicu entitas atau Multinasional Coorporation membuka cabang/ anak perusahaan di Negara-nagara yang memiliki tingkat pajak yang lebih rendah dari Indonesia, sehingga pada akhirnya menimbulkan transfer pricing untuk transaksi perusahaan induk ke anak-anak perusahaannya yang ada di Negara-negara yang tingkat pajaknya relative lebih rendah dari Negara asal tempat entitas induk berdiri..

\section{H2 : Tunneling berpengaruh Positif terhadap transfer pricing H2 DITOLAK}

Hasil anaalisis statistic menunjukkan variabel Tunneling tidak signifikan mempengaruhi keputusan melakukan transfer pricing. Kondisi ini dibuktikan dengan hasil analisis significan Tunneling berada di atas standar significan yaitu 0,255 > dari 0,05. Jadi hasil analisis ini menyatakan bahwa variabel Tunneling tidak signifikan terhadap perilkau Transfer Pricing.

Tunneling merupakan perilaku manajemen atau pemegang saham mayoritas yang mentransfer aset dan profit perusahaan untuk kepentingan mereka sendiri, namun biaya dibebankan kepada pemegang saham minoritas. Kondisi isi dapay menstimulus terjadinya transfer pricing karena adanya power kekuasaan untuk mengarahkan bonus intensif yang didapatkan dari laba ditahan atau laba bersih perusahaan, selain itu power ini mengarahkan entitas induk untuk mentranfer penjualan ke anak-anak perusahaan yang ada yang nota benenya adalah milik dari pemegang saham mayoritas di perusahaan induk (Multinasional).

Dalam membuat keputusan transfer pricing diperlukan dukungan dan persetujuan dari dewan komisaris, direksi dan semua pihak yang terlibat dalam perusahaan termasuk pemilik saham minoritas, tidak hanya berdasarkan pada keinginan pemilik saham mayoritas saja, sehingga hal tersebut tidak berpengaruh terhadap keputusan transfer pricing perusahaan. Realitas ini Nampak pada corporation yang bergerak dibidang Outomotif, sebagai sampel dalam penelitian ini, sehingga hasil statistik menyatakan, bahwa varibal "tunneling", tidak berpengaruh terhadap perilaku transfer pricing.

\section{H3: Gross Profit berpengaruh positif terhadap transfer pricing}




\section{H3 DITOLAK}

Hasil anlisis statistic bahwa variabel Gross Margin tidak signifikan mempengaruhi keptusan perusahaan untuk melakukan Tranfer Pricing. Kondisi ini dibuktikan dengan hasil analisis statistic regresi variabel Gross Margin sebesar 0,543 > 0,05.. Jadi hasil anlisis ini menunjukkan Gros s Margin tidak signifikan mempengaruhi Transfer Pricing

Variabel independen gross margin perusahaan tidak terlalu berpengaruh terhadap keputusan transfer pricing yang dilakukan oleh perusahaan yang bertaraf Multinasional. Tansfer pricing dilakukan untuk menghindari pembayaran pajak dengan seolah-olah perusahaan mendapatkan profit atau laba yang rendah. Motifasi perilaku transfer pricing juga dimotifasi dengan cara menitik beratkan pada produk barang yang dijual/ ditransfer dengan harga spesial (lebih rendah dari harga umumnya), sehingga setelah dikurangi dengan harga pokok produksi, gross marin menjadi lebih kecil dan akibatnya PPh akan terlihat lebih rendah. Penjualan dengan harga yang lebih rendah tentu akan berdampak pula pada pengenaan PPN yang lebih kecil. Kondisi ini memang sangat memungkinkan terjadi di dunia perdagangan bak nasional maupun mancanegara.

Perilaku dalam penetapan gross margin, ternyata tidak didominasi oleh perlikau memainkan tingkat harga barang penjualan dengan melakukan traner pricing, Namun cendrung lebih dominan dengan melakukan peningjatan efektifitas dan efesiensi kinerja manajemen di semua difinisi atau departemen.

Aktifitas Peningkatan efektifitas dan efesiensi kinerja (tingkat laba) perusahaan lebih khusus ditujukan pada departemen produksi, pemasaran dan penjualan, yang dilakukan dengan menerapkan strategi aplikasi ABM (Aktifity Base Manajemen) untuk menghasilkan TQM (Total Quality Manajemen). TQM untuk menghasilakn efektifitas dan efesiensi diwujudkan dengan menerapkan berbagai pendekatan, seperti: ABC (Aktifity Base Costing) dengan JIT (Just In Time) Sholar Chain, pembentukan Biaya Standar sebagai sistem control (Standar Cost) dan BalanceSchorkat. Jadi aktifitas dominan untuk peningkatan laba perusahaan (Multinational) tidak didominasi oleh perilaku penghindaran pajak dengan Ttransfer Pricing, melainkan cenderung dengan strategi realisasi efektifitas dan efesiensi laba perusahaan dengan strategi manajemen di atas.Kondisi inilah yang menyebabkan variabel Gross Margin tidak berpengaruh signifikan terhadap variabel Tranfer Pricing.

\section{H4: KAP Spesialis Pajakberpengaruh Positif terhadap transfer pricing}

H4 DITOLAK 
Hasil analisis statistic menunjukkan bahwa variabel KAP tidak significan mempengaruhi keputusan melakukan Transfer Pricing. Pernyataan ini ditunjukkan dengan hasil anlisis statistic variabel KAP Spesialis berada di atas statndat signifikan, yaitu $0,380>0,05$. Hasil analisis ini mempekuat pernyataan bahwa Gross Margin tidak berpengaruh terhdap Transfer Pricing

Audit Eksternal menyediakan keahlian khusus pajak melalui provesi dari konsultan pajak guna memberikan pelayanan kepada kliennya (perusahaan). Namun, bukan pelayanan untuk melakukan kecurangan. Audit eksternal hanya akan memberikan solusi yang terbaik untuk perusahaan dan tidak akan memberikan informasi yang menyesatkan kepada pengguna laporan keuangan, karena apabila hal tersebut dilakukan audit eksternal tersebut akan terkena sanksi hukum dan pidana yang cukup berat.

Eksistensi sebagai Kantor Akuntan Publik yang professional dan berkarakter, mengharuskan KAP spesialis sebagai konsultan atau pengarah dalam hal perilaku perpajakan selalu ingin memberikan arahan bimbingan yang tidak meyimpang dari ketentuan undang-undang perpajakan. Kondisi professional sebagai KAP yang besar berskala Multinasional ini juga yang semakin membuat KAP selalu memberikan pelayanan terbaik dalam peningkatan efesiensi pajak dengan cara lain yang tidak melanggar undang, bukan dengan model tranfer pricing. KAP spesialis dengan kondisi psikologis ini membuat variabel independen ini, tidak berpengaruh terhadap variabel dependen transfer pricing.

\section{KESIMPULAN DAN SARAN}

\section{Simpulan}

Setelah melakukan penelitian dengan pembhasan dan pengolahan statistik, maka dapat disimpulkan hasil penelitian terhadap variabel-variabel independen seperti Pajak, Turnneling, Gross Margin dan KAP Spesialis terhadap perilaku keputusan melakukan Transfer Pricing dapat diuraikan antara lain:

1. Secara parsial Variabel Independen Pajak sangat dominan mempengaruhi atau signifikan mempengaruhi keputusan melakukan Tranfer Pricing. Kondisi ini disebabkan variabel pajak ini adalah unsur yang paling besar mempengaruhi pengurangan terhadap profit atau sumber pendapatan perusahaan. Selain itu variabel pajak memilki banyak bentuk pajak yang dikenakan terhadap bergai objek pajak. Kondisi ini dipicu lagi oleh adanya penerapan tarif pajak yang berbeda antara satu negara dengan negara lain., sementara bayak Negara-negara yang tariff pajaknya relative jauh lebih dari Negara Indonesia. Kondisi inilah yang sangat memicu unsure 
pajak adalah varibel yang sangat dominan mempengaruhi keputusan mengambil sikap melakukan Tranfer Pricing.

2. Secara parsial variabel independen selain pajak, yaitu Turnneling, Gross Margin dan KAP Spesialist tidak berpengaruh signifikan terhadap sikap keputusan melakukan Tranfer Pricing. Hal dikrenakan. Manjemen untuk Perusahan yang bergerak di bidang industry outomotif lebih tertarik dan focus melakukan efektifitas dan efesiensi untuk peningkatan profit perusahaan dengan jalan mnerapkn Strategi Manajemen. Seperti penrapan mewujudkan TQM (total quality manajemen) dengan pendekatan ABC, Solar Chain, JIT, Biaya Standar, BEP, Balance Scorecard

3. Secara simultan seluruh variabel independen, ternyata tidak signifikan terhadap keputusan melakukan Tranfer Pricing. Koondisi memungkinkan terjadi mengingat jumlah data yang terbatas dar penelitian ini yang objek penelitiannya berjumlah 30 sampel. Perushan yang diambil hanya entitas yang bergerak d bidang Automotif saja yang jmlahnya hanya 6 perusahaan.Kondisi ini dapat dimungkinkan dengan melihat variabel independen ini hanya menjelaskan pengaruh terhadap transfer pricing hanya $18 \%$ san persen, selebihnya terdapat varibel lain yang mempengarugi perilku Tranfer Pricing hingga 8\%.

\section{Saran}

Dari hasil anasis statistic, variabel pajak menunjukkan variabel yang paling dominan memberikan pengaruh signifikan terhadap keputusan melakukan Transfer Pricing untuk sampel penelitian dari perusahaan industry khisus outomotif yang hanya terdiri dari 6 perusahaan 30 sampel. Kondisi ini menunjukkan pemerintah atau dirjen pajak dan pihak-pihak yang terkait dengan regulasi pajak dan ekonomi, perlu untuk secara intensif mengevaluasi tingkat Tarif Pajak yang terbaik. Karena dengan demikian akan mampu meredam perilaku transfer pricing dan sikap perilaku penggelapan pajak tax Avoiden maupun tax avoisen. Kebijakan penetapan tariff pajak yang fleksibel dan bijaksana terus menyesuaikan dengan situasi dan kondisi perkembangan ekonomi nasional maupun international, kemungkinan akan mampu menggairahkan susanan prenomian nasional dan sekaligus mampu meredam perlku transfer Pricing. Selain kebijakan penetapan tariff pajak yang terus dinamis, juga perlu diperhatikan variabel gros margin. Tunneling dan KAP spesialis agar tidak mempengaruhi perliaku transfer Pricing karena pada industi perusahaan yang lain dalam skala yang lebih luas ternyata berdasarkan penelitian dari para peneliti yang lain juga mempengaruhi perilaku Tranfer Pricing. Jadi para regulator perlu membuat aturan jelas dan 
Lalu Takdir Jumaidi, Bambang \& Robith Hudaya : Analisis Pajak, Tunneling, Gross Margin.....

tegs serta perangkat sistem yang lebih baik dalam mendeteksi terjadinya transfer Pricing sehingga perlaku Tranfer Pricing dapat diantisipasi lebih baik.

\section{Daftar Pustaka}

Anggraini, Ririn Dwi, 2011, Pengaruh Kepemilikan Institusional dan Kepemilikan Asing Terhadap Pengungkapan Pertanggung Jawaban Sosial Perusahaan Dalam Annual Report, Skripsi, diakses dari http://eprints.undip.ac.id pada tanggal 19 Juni 2014.

Anonim. 2009. Undang-undang Nomor 6 Tahun 1983 sebagaimana telah diubah terakhir dengan Undang-undang Nomor 16 Tahun 2009 tentang Ketentuan Umum dan Tata Cara Perpajakan.

Anonim. 2011. Peraturan Direktur Jendral Pajak Nomor PER: 43/PJ/2010 sebagaimana telah diubah terakhir dengan Peraturan Direktur Jendral Pajak Nomor PER: 32/PJ/2011 tentang Penerapan Prinsip Kewajarandan Kelaziman Usaha dalam Transaksi antara Wajib Pajak dengan Pihak yang Mempunyai Hubungan Istimewa

Balsam, S., J. Krishnan, and J. Yang. 2003. Auditor industry specialization and earnings quality. Auditing: A Journal of Practice and Theory 22: 71-97.

Blaylock, B., T. Shevlin, and R. Wilson. 2009. Tax avoidance, large positive book-tax differences, and earnings persistence. Working paper, University of Washington

Colgan, P. Mc. 2001. "Agency Theory and Corporate Governance: A Review of the Literature From a UK Perspective". Working paper.

Ghozali, Imam. 2006. Aplikasi Analisis Multivariate dengan Program SPSS. Semarang: BP Undip.

Gleason, C. and L. Mills. 2007. Do auditor-provided tax services improve the estimate of tax expense? Working paper, University of Iowa and University of Texas

Gul, F., S. Fung, and B. Jaggi. 2009. Earnings quality: Some evidence on the role of auditor tenure and auditors' industry expertise. Journal of Accounting and Economics 47: 265-287.

Peraturan Direktur Jenderal Pajak Nomor PER-32/PJ/2011 tentang Penerapan Prinsip Kewajaran dan Kelaziman Usaha dalam Transaksi Antara Wajib Pajak dengan Pihak yang Mempunyai Hubungan Istimewa.

Pernyataan Standar Akuntansi Keuangan (PSAK) Nomor 7 tentang Pengungkapan Pihak-Pihak yang Mempunyai Hubungan Istimewa

Sudarmaji, Ardi Murdoko dan Lana Sularto, 2009, Pengaruh Ukuran Perusahaan, Profitabilitas, Leverage dan Tipe Kepemilikan Perusahaan Terhadap Luas Voluntary Disclosure Laporan Keuangan Tahunan, 
Skripsi, diakses dari http://ejournal.gunadarma.ac.id pada tanggal 20 Maret 2014

Undang-Undang Nomor 36 Tahun 2008 tentang Pajak Penghasilan.

Yuniasih, Ni Wayan, Ni Ketut Rasmini dan Made Gede Wirakusuma, 2011, Pengaruh Pajak dan Tunneling Incentive Pada Keputusan Transfer Pricing Perusahaan Manufaktur Yang Listing Di Bursa Efek Indonesia, Skripsi, diakses dari http://ojs.unud.ac.id pada tanggal 28 Maret 2014.

Watt,Ross\& Jerold L.Zimmerman(1986), Positive Accounting Theory, PrenticeHall,Inc, Englewood Cliffs, New Jersey. 